\title{
ANALYSIS OF PROFITABILITY PERFORMANCE BASED ON THE PROBLEM FINANCING SECTOR IN BPRS IN BEKASI CITY
}

\author{
Hamzah Robbani*, Prasetio Ariwibowo**, Deny Heryadi*** \\ Universitas Indraprasta PGRI Jakarta \\ *hamzahrabbani8@gmail.com \\ **Prasetio.ariwibowo@yahoo.com
}

\begin{abstract}
This study aims to determine the effect of problematic financing on profitability in Sharia People's Financing Banks (BPRS) in the City of Bekasi and the efforts of the management of the Islamic People's Financing Bank (BPRS) in Bekasi City in overcoming problematic financing. This research is "qualitative" namely research that studies a number of information relating to financing. To process data in this study using quantitative analysis in the form of Simple Regression analysis (Likert scale), and Coefficient of Determination Test (R2) with SPSS version 23.00. The results of data processing by researchers have the value of validity and reliability can be used as the basis for retrieval of data, and the results of simple regression analysis with $r$ square of 0.047. shows that $\mathrm{HO}$ is accepted which shows that there is no significant effect of Non Performing Financing on Profit in BPRS in Bekasi City.
\end{abstract}

Keywords: Profitability, Financing, BPRS, Non Performing Financing. Bekasi

\section{INTRODUCTION}

Today, the level of competition between banks in Indonesia has become increasingly sharp in providing services to its customers. Every bank has various types of services that are in accordance with the wishes of customers both in terms of products and in terms of services / services to customers.

According to Ariwibowo (2016), Indonesia's economic growth rate experienced quite sharp sluggishness beginning in 2013, the rate of economic growth was $5.56 \%$ compared to 2012 . In 2014 , the level of the economy was only able to grow by $5.02 \%$ (down $0.54 \%$ compared to 2013 ) and in 2015 , the economic growth rate in Indonesia was $4.79 \%$ (down 0.23 from 2014). The increasing income of business people causes the results of economic development in a region. Bekasi is

Manazhim : Jurnal Manajemen dan Ilmu Pendidikan

Volume 1, Nomor 2, Agustus 2019; 117-129

https://ejournal.stitpn.ac.id/index.php/manazhim 
one of the cities that experiences very sharp economic development growth and varies from year to year so it requires large funding. Therefore, the role of banking and non-banking financial institutions as one of the sources of funding through savings and loans is needed. Banking is directed to play a role as an agent of development that aims to develop the implementation of national development, economic growth, and national stability towards improving the standard of living of the people. Indonesian banking is commissioned by the government to participate in implementing government programs to develop certain economic sectors or give greater attention, especially to lower and middle class economic entrepreneurs in order to improve the lives of many people.

According to the Islamic view, the issue of credit with the stipulation of interest is considered usury by the scholars with the arguments in the Qur'an surah Ar-Rum verse 39 which reads:

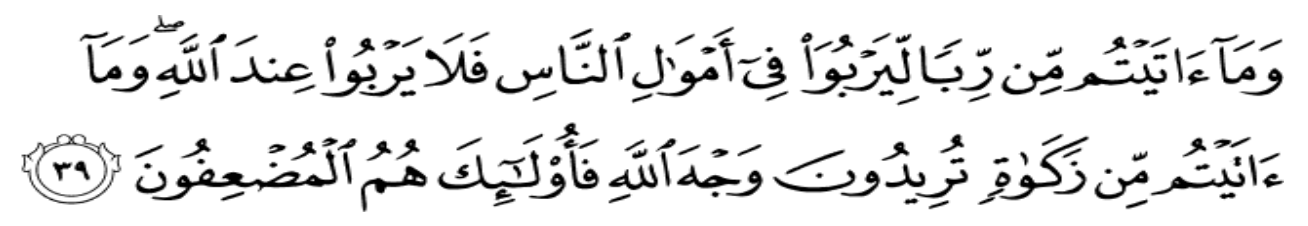

Translation: "... And something usury (extra) that you give so that he increases in human property, then usury does not add to the side of Allah. And what you give is in the form of zakat that you mean to achieve the pleasure of Allah, then those who do that multiply (reward) ".

The paragraph above explains that a loan (credit) with an interest system will not bring blessings to the economy of the community. From the point of view of Islam, this clue is in stark contrast to most human views. Some people argue that loans with an interest system will improve the economy of the community, while according to Allah SWT in His word, loans with interest systems do not make the economy grow and develop.

Funding carried out by Sharia Banks is inseparable from the risks that must be anticipated by the Bank in this musyarakah financing mechanism. Negligence deliberately by the customer not to pay installments, is the most common problem in the implementation of financing. This greatly affects the Bank because it can cause the Bank to suffer losses due to default installments. In addition to the risks caused 
by customers who carry out this financing, there are also risks that can be caused internally from the Syariah Bank itself, namely the part that handles the financing problem. Here they deal with customers who propose financing can deliberately not carry out the principle of prudence properly so that it can harm the Islamic Bank itself. Financing risk can affect the level of profitability of Islamic banks, this is because when the amount of problematic financing becomes large, the greater the amount of the cost of the provision for elimination of financing that affects the ability of banks to generate profits. Therefore, the financing and investment carried out must be maintained and managed carefully so that it becomes non-problem financing.

The application of financing analysis is confirmed in Law No. 21 of 2008, hereinafter referred to as the Sharia Banking Law, that in channeling financing / credit and conducting other business activities, Sharia Banks must take measures that do not harm Sharia Banks and the interests of customers who entrust their funds and also state that Sharia Banks must implement risk management, the principle of knowing customers and customer protection.

In Islam, financial and banking activities are seen as a vehicle for the community to bring them to, at the very least, the implementation of two teachings of the Qur'an, namely the principle of mutual cooperation (helping and working together between members of the community for good) and the principle of avoiding al-iktinaz (holding and allowing idle funds and not playing for beneficial transactions). One of the vital functions of banking is as an institution that has the role of receiving deposits from customers and lending them to other customers who need funds. For conventional banks, the spread between the amount of interest charged to borrowers of funds in return for interest given to depositors is the biggest source of profit. The main principle adopted by Islamic banks is the prohibition of usury (interest) in various forms of transactions, conducting business and trading activities based on sharia, as well as growing zakat.

Based on the results of research conducted by Azharsyah Ibrahim and Arinal Rahmati (2017) entitled "Solutive Analysis of Settlement of Problematic Financing in Islamic Banks: Study of Murabahah Products at Bank Mumalat Indonesia Banda Aceh" states that there are three factors causing problematic murabahah financing, 
namely customer factors, bank internal factors and fictitious factors. The policies implemented to improve the quality of payments and reduce NPF began with prevention efforts until efforts to resolve troubled financing. Specifically, the financing settlement policy has problems with BMI through OTS, billing, summons, restructuring, selling guarantees, writing off and establishing fines and forming special teams that handle problem financing. In addition, BMI also has internal policy patterns that are not regulated in detail in PBI. This internal policy is tailored to the culture of customers and the surrounding community so that it can differ from one customer to another. This policy is applied when the existing rules are considered insufficient to reduce the NPF ratio. The implementation of non-performing financing policies has proven to have positive implications for improving payment quality and decreasing the NPF ratio. Nevertheless, the decline in the NPF ratio can also be attributed to economic growth and an increase in the income of the Acehnese as a whole. Economic growth is an important measure in explaining economic performance which is directly the performance of economic actors who provide goods and services including banking itself. Economic growth can increase bank cash flow by increasing demand for financing by customers. Along with increasing economic growth, there will be an increase in payments, thereby reducing NPF. Conversely, when an economic slowdown will affect the ability of customers to pay installments to the bank. Referring to BPS data, in the study period (2015-2016) there was a significant economic growth in Aceh. At the end of 2015, Aceh's economic growth was only recorded at $0.72 \%$ where there was a slowdown from $1.65 \%$ in 2014. Then as of August 2016 there was an increase to 3.54\%. Based on these assumptions, there is a close link between the increasing number of NPFs in 2015 and the economic slowdown in Aceh and the improvement in the quality of payments in 2016 along with Aceh's economic growth that year. In other words, economic growth has an important role in the quality of loan payments given by BMI. If economic growth declines in the form of a negative trend, this will have an impact on the deteriorating quality of payments. Theoretically, economic growth is caused by an increase in economic transactions, as well as the growth of the business world. With this condition it can be concluded that the policies that have been 
implemented by BMI will run effectively in reducing the NPF ratio if supported by economic growth factors that contribute to increasing customer income.

This was also strengthened also based on the results of research conducted by Zaim Nur Afif as a Bachelor of Islamic Economics Program Faculty of Airlangga University Surabaya and Imron Mawardi as a lecturer in the Sharia Economics Faculty of Airlangga University Surabaya (2014) in the journal JESTT Vol. 1 No. August 8, 2014, it can be seen that:

1. Murabahah financing has a positive effect on troubled financing of sharia commercial banks during the 2009-2013 period with a path coefficient of 0.874. This shows that every increase in the amount of one unit in the amount of murabahah financing will increase the number of problematic financing by 0.874 units.

2. Problematic financing does not affect the profit of sharia commercial banks during the period of 2009-2013. Thus, any increase in the number of problematic financing by one unit will not increase or decrease the value of profit.

3. Murabahah financing has a positive effect on the profit of sharia commercial banks during the 2009-2013 period with a path coefficient of 0.793 . It shows that every increase of one unit in the amount of murabahah financing will increase the amount of profit by 0.793 units.

4. There is an indirect influence between murabahah financing on earnings through intervening endogenous variables, namely problem financing. The results of path analysis for the indirect effect is 0.053 . This shows that the indirect effect is smaller than the direct effect of 0.793 because the results of this study are that problem financing does not affect earnings. Therefore, the analysis of murabahah financing variables on profits can only be analyzed through direct influence. 
Based on the description of the background above, the author draws on the problem, as follows:

1. How is the influence of problematic financing on profitability in the Sharia People's Financing Bank (BPRS) in Bekasi City?

2. What are the efforts of the management in overcoming the problematic financing of the BPRS in Bekasi City?

Based on the aforementioned background and the aforementioned problems, this study aims to find out how the influence of problematic financing on profitability in BPRS in Bekasi City, and to find out how the management of the BPRS in the City of Bekasi in overcoming problematic financing.

\section{RESEARCH METHODS}

The population in this study is all of the customers and employees in the Syariah Patriot Bank (BPRS) Patriot Bekasi, Sharia Community Financing Bank (BPRS) Harta Insan Karimah (HIK) Bekasi, Sharia Community Financing Bank (BPRS) Artha Karimah Irsyadi Bekasi which is used as the object of research to obtain the desired information and data. The technique used by the author in determining the sample is saturated sampling, namely the employees of the Sharia Islamic Bank (BPRS) Patriot Bekasi, Sharia People's Financing Bank (BPRS) Harta Insan Karimah (HIK) Bekasi, Artha Karimah Syariah Islamic Financing Bank (BPRS) Irsyadi Bekasi specifically deals with financing problems. The number of samples in this study were 10 people in each SRB. To obtain information and data as the material of this writing using data collection methods in the form of observation and study of literature.

To prove the hypothesis proposed, this study uses a qualitative analytical analysis method to study, analyze and explain the effect of problematic financing on profitability at the Sharia Islamic Bank (BPRS) Patriot Bekasi, Sharia Community Financing Bank (BPRS) Harta Insan Karimah (HIK) Bekasi, Sharia Community Financing Bank (BPRS) Artha Karimah Irsyadi Bekasi. Quantitative analysis is an analysis that interprets data in the form of numbers. This analysis is used as a statistical tool, making it easier for writers to interpret the raw data obtained. This 
effort uses a Likert scale where the answer or questionnaire is given weight. The next method uses Simple Regression Analysis and Coefficient of Determination Test (R2), to be able to provide an interpretation of the correlation coefficient found to be large or small, then it can be guided by the significance level of problematic financing relationships with profitability in BPRS in Bekasi.

\section{RESEARCH RESULT}

Sharia People's Financing Banks (BPRS) in carrying out their business must comply with the bank's health signs in order to maintain their existence. The application of the precautionary principle by BPRS is nothing but to guarantee the security of public funds, which will have an impact on public trust in the existence of Islamic banks. The role of the BPRS in this case is to increase the business of the BPRS. Based on data obtained from the implementation of research in the Sharia Patriot Bank (BPRS) Bekasi, Sharia People's Financing Bank (BPRS) Harta Karimah (HIK) Bekasi, and Sharia People's Financing Bank (BPRS) Artha Karimah Irsyadi Bekasi, the researcher will present some primary data that has been processed.

\section{General Analysis of Variables on the Effect of Problem Financing (X)}

a. Based on the results of the questionnaire, it shows that the answers agree with the frequency level of $100 \%$. This means that the SRB analyzes before providing financing to customers.

b. Based on the results of the questionnaire, it shows that the answers agree with the frequency level of $100 \%$. This means that the SRB has the right to request collateral for the financing made, as collateral if the customer makes a deviation from financing.

c. Based on the results of the questionnaire, it shows that the answers agree with the frequency level of $97.77 \%$. This means that the SRB has the right to sell collateral, if the customer is no longer able to pay his debt to the SRB.

d. Based on the results of the questionnaire, it shows that the answers agree with a frequency level of $95.5 \%$. This means that supervision is carried out by BPRS continuously in providing financing to customers. 
e. Based on the results of the questionnaire, it shows that the answers agree with a frequency level of $95.5 \%$. This means that before providing financing customers are required to follow the procedures set by the BPRS.

f. Based on the results of the questionnaire, it shows that the answers agree with the frequency level of $93.3 \%$. This means that the BPRS is a Bank whose operational system uses sharia principles.

g. Based on the results of the questionnaire, it shows that the answers agree with the frequency level of $97.7 \%$. This means that with the existence of Islamic banks it can help the economy of the community.

h. Based on the results of the questionnaire, it shows that the answers agree with a frequency level of $96.6 \%$. This means that the financing carried out in the SRB must be in accordance with Islamic sharia principles.

i. Based on the results of the questionnaire, it shows that the answers agree with the frequency level of $89.4 \%$. This means that financing of BPRS activities and funding for customers must be obtained from sources that are truly protected from usury.

j. Based on the results of the questionnaire, it shows that the answers agree with the frequency level of $89.6 \%$. This means that there is a fundamental difference between BPRS and conventional banks which is located in the operational system.

2. General analysis of profitability variables $(\mathrm{Y})$

a. Based on the results of the questionnaire, it shows that the answers agree with the frequency level of $88.8 \%$. This means that the Customer is a bank user.

b. Based on the results of the questionnaire, it shows that the answers agree with the frequency level of $87.7 \%$. This means that the profits or profits obtained from the SRB must be in accordance with the provisions of the Islamic Shari'a or truly avoid usury.

c. Based on the results of the questionnaire, it shows that the answers agree with the frequency level of $87.7 \%$. This means that with the presence of an SRB the community is far from poverty. 
d. Based on the results of the questionnaire, it shows that the answers agree with the frequency level of $88.8 \%$. This means that it agrees with the due date in the BPRS with a nominal and tenor amount of payment between the BPRS and the customer.

e. Based on the results of the questionnaire, it shows that the answers agree with the frequency level of $86.6 \%$. This means that the contracts used in providing financing are clearly displayed.

f. Based on the results of the questionnaire, it shows that the answers agree with the frequency level of $86.6 \%$. This means that debtor customers are customers who obtain facilities.

g. Based on the results of the questionnaire, it shows that the answers agree with the frequency level of $86.6 \%$. This means that long-term financing and short-term financing.

h. Based on the results of the questionnaire, it shows that the answers agree with the frequency level of $85.5 \%$. This means that the function of a banking facility is as an institution that plays a role in receiving deposits and lending to other customers in need.

i. Based on the results of the questionnaire, it shows that the answers agree with the frequency level of $84.4 \%$. This means that in channeling financing or other business activities the BPRS must take steps that do not harm the bank or the customer.

Based on the regression test using SPSS 23.0 the results of the regression test (reliability) are as follows

Table 1. Alpha Cronbach's Reliability Regression Test

\section{Reliability Statistics}

Cronbach's

\begin{tabular}{r|r} 
Alpha & N of Items \\
\hline .872 & 19 \\
\hline
\end{tabular}

Based on the results of the reliability calculation, Alpha Cronbach's value is 0.872 , which means the questionnaire instrument used is realible. 
Linear regression test is a regression in which the independent variable has the highest rank one. Data from questionnaires that were distributed, analyzed data with simple linear regression and showed the results of data analysis showed a Sig value of 0.250 > Source: Primary Data Results by SPSS 23.00 version (2019) 0.05, which means there is a significant effect. Based on the results of data analysis, it can be concluded that the regression line equation is $\mathrm{Y}=21,561+0.288(\mathrm{x})$.

Furthermore, to determine the effect of problematic (independent) financing variables on profitability (dependent) variables, partial testing was carried out using the $\mathrm{t}$ test.

Table 2. T test

Coefficients ${ }^{2}$

\begin{tabular}{l|r|r|r|r|r}
\multicolumn{2}{c|}{ Unstandardized Coefficients } & \multicolumn{2}{|c|}{ Standardized Coefficients } & & \\
Model & B & Std. Error & Beta & T & Sig. \\
\hline 1 (Constant) & 21.561 & 6.364 & .217 & 1.175 & .250 \\
\hline PROFIT & .288 & .245 & & 3.388 & .002 \\
\hline
\end{tabular}

Source: Primary Data Results by SPSS 23.00 version (2019)

Hypothesis testing is a procedure that is carried out to decide whether to accept or reject the hypothesis regarding population parameters. The results of the calculation of hypothesis testing in this study indicate that $\mathrm{t}$ count 1.175 and t table 2.04841 (DF $=28$ ) which shows that $\mathrm{HO}$ is accepted that $\mathrm{t}$ count is greater than $\mathrm{t}$ table, which means there is no significant influence between Non Performing Finance on the BPRS Profit in Bekasi City.

Table 3. Determination Test

Model Summary ${ }^{\mathrm{b}}$

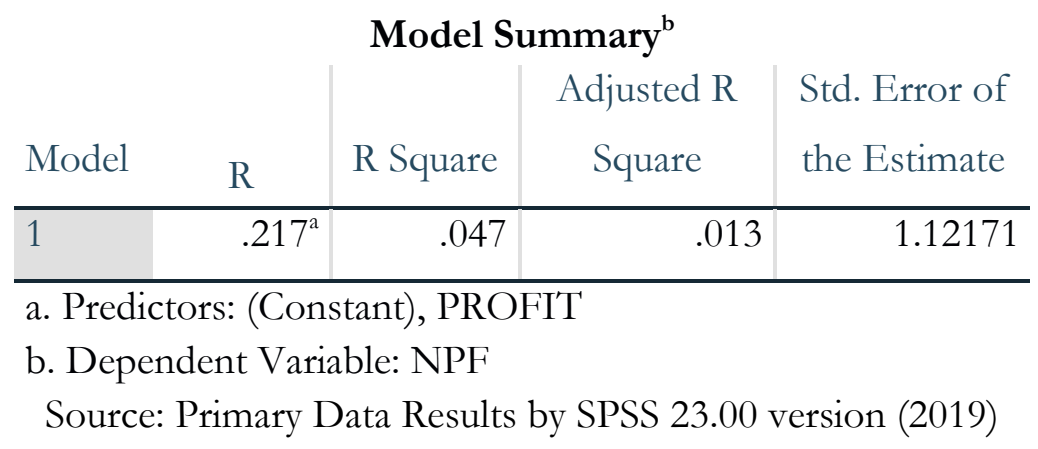


From the results of the above calculations show $r$ square of 0.047 . These results indicate that the NPF did not have a significant impact on profit in the BPRS in Bekasi. In the operation implemented by the BPRS, it always cooperates with the ZISWAF (Zakat Infak Shodaqoh Wakaf) instrument as a symbol, that profit and non-profit economic activities always hold hands. This makes it possible if there are debtors who fail to pay and are unable to repay their obligations to the BPRS to be finalized with ZISWAF funds and still refer to the procedures and requirements that the debtor is in the worst position and fall into the asnaf zakat category, Gharimin. as explained by Setyoraty (2017) ". For the Gharimin group (people who owe), zakat funds can be allocated to free debts of people who are in debt, freeing traders from debt capital to banks and so on.

\section{CONCLUSION}

Questionnaires that are used as research instruments for data retrieval by researchers have validity and reliability values that can be used as a basis for data collection for Non Performing Financing and Profit variables in BPRS in Bekasi City. The results of a simple regression analysis show that $\mathrm{HO}$ is accepted which shows that there is no effect of Non Performing Financing on Profit in BPRS in Bekasi City. In Sharia financial institutions, the operations implemented by BPRS always hold the ZISWAF (Zakat Infak Shodaqoh Wakaf) instrument as a symbol that profit and non-profit economic activities always hold hands. This makes it possible if there are debtors who fail to pay and are unable to pay off their obligations to the BPRS to be finalized with ZISWAF funds and still refer to the procedures and requirements that the debtor is in the worst position and enter the asnaf zakat category namely Gharimin. So for the Gharimin group (people who are in debt), zakat funds can be allocated to free debts for people who are in debt, freeing traders from debt capital to banks and so on.

This was confirmed by Badarudin (2011) that the contribution of BPRS Qardhul Hasan's financing to customers has a very large problem, because with this funding they are greatly helped as parties who need help because their needs are very urgent. In BPRS Metro Madani, Qardhul Hasan's funding was given to two parts, 
namely people who were affected by sickness and lack of funds, and people who were in debt and needed immediate repayment.

\section{SUGGESTION}

In further research so that independent vadiables are added in the form of Efficiency, Margin Growth, non-business income such as PPOB transfer fees, and others.

\section{BIBLIOGRAPHY}

Journal Article Online version

Afif, Zain Nur. Mawardi, Imron. 2014. Pengarub Pembiayaan Murabahab Terbadap Laba Melalui Variabel Intervening Pembiayaan Bermasalab Bank Umum Syariah di Indonesia Peride 2009 - 2013. Jurnal JESTT Vol. 1 No. 8 Tahun 2014, Hal. $565 \quad-580 . \quad$ DOI $\quad$ : $\quad$ https://ejournal.unair.ac.id/JESTT/article/view/520/323. Diakses Pada 05 April 2019.

Ariwibowo, Prasetio. 2016. Fundamental Pertumbuhan Perekonomian Di Indonesia. Journal of Applied Business and Economics. Volume 2 Nomor 3 Maret 2016, $\begin{array}{llllll}\text { Page } & 232 & - & 245 . & \text { DOI }\end{array}$ https://journal.Ippmunindra.ac.id/index.php/JABE/article/viewFile/1485/118 8

Bank Indonesia. 2008. Undang-Undang Republik Indonesia Nomor 21 Tabun 2008 Tentang Perbankan Syariah. DOI :

https://www.bi.go.id/id/perbankan/syariah/Documents/UU_21_08_Sya riah.pdf

. Diakses pada 22 Februari 2019.

Ibrahim, Azharsyah. Rahmati, Arinal. 2017. Analisis Solutif Penyelesaian Pembiayaan Bermasalab Di Bank Syariah : Kajian Pada Produk Murababah di Bank Muamalat Indonesia Banda Aceh. Jurnal Iqtishadia : Jurnal Kajian Ekonomi dan Bisnis Islam STAIN Kudus Vol. 10 No. 1 Tahun 2017 Halaman 71 96. DOI : https://www.neliti.com/publications/91301/analisis-solutifpenyelesaian-pembiayaan-bermasalah-di-bank-syariah-kajian-pada. Diakses pada 5 April 2019.

Joni dan Lina. 2010. Faktor-faktor yang Mempengarubi Struktur Modal. STIE Trisakti. Jurnal Bisnis dan Akuntansi. Vol. 12, No.2, Agustus 2010, Halaman 81-96.

Kementerian Agama Republik Indonesia, Alquran dan Terjemahannya. Bandung: Penerbit Jumanatul Ali-Art, 2004. 
Deny Heryadi, Prasetio Ariwibowo, Hamzah Robbani

Thesis

Badarudin. 2011. Manajemen Pembiayaan Produk Qardhul Hasan (Studi Kasus di BPRS Metro Madani, Lampung Tabun 2011). Yogyakarta : UIN Sunan Kalijaga. DOI : http://digilib.uin-suka.ac.id/6891/1/BAB\%20I\%2CV.pdf

The Holy Qur'an

Q.S. Ar-Rum verse 39 